\title{
Use of electronic databases by South African visual artists: a cross-sectional study
}

\author{
Carol van $\mathrm{Zij}^{*}$ \\ Vaal Triangle Technikon \\ carolvz@tritek.ac.za- \\ Elizabeth M. Gericke \\ University of South Africa
}

\begin{abstract}
Received: 1 October 2001
Revised: 9 April 2002

This article is based on part of a cross-sectional survey conducted as the empirical component of a Masters' dissertation submitted to the University of South Africa. The extent to which visual artists use certain wellknown art-related databases that are available either online or on CD-ROM was investigated. Artists also had to indicate how successful they were in finding the required information on databases. It was found that South African artists have low levels of interest in, and awareness of, these databases. Although the sample used included only the more information-literate artists such as lecturers, high school art teachers and members of art societies, it was apparent that the majority of the respondents had never used most of the databases in question. The independent variables of gender, age, working affiliation, qualifications and field of artistic interest have a decisive influence on the degree of interest shown in the databases. The perceived success in searching the databases is also influenced by these variables.
\end{abstract}

\section{Introduction}

Due to the rapid growth in the provision of electronic information sources in the field of the visual arts, research into the inroads they are making into the information world of artists has become necessary.

The problem addressed in this investigation into the use made of electronic databases is to establish how useful the various databases covering the visual arts are to artists in general, and whether certain groups of artists benefit more from the use of electronic databases than other groups. An additional aspect of the problem is to determine how successful artists are in searching databases and whether training has any effect on successful searching of electronic databases.

\section{Literature review}

There are certain significant differences between online information services, such as the Internet, and CD-ROM sources. Because of the high cost of producing CD-ROM products, coverage of art on CD-ROM is less extensive than on online sources like the World Wide Web (WWW). CD-ROMs tend to be limited to art treasures by the great masters, famous art galleries and artists and renowned architectural edifices (Jacso \& Tiszai 1996:14). Even lesser known artists and artworks can often be found on the Internet, but the intricate attention to detail that is possible using CD-ROM databases is usually lacking on the Internet. Griffin (1997:64) encourages the use of CD-ROM databases because of the way this technology enables artists to obtain a more comprehensive picture of the art they are studying. The number of such databases is growing at present and most major museums now have commercially or privately produced CD-ROMs of their collections.

Several bibliographic databases are now also produced on CD-ROM, and other researchers have found that artists find them valuable. Sykes-Austin (1991:13), for example, carried out a survey relating to the print and CDROM versions of Art Index and found that users showed a convincing preference for the CD-ROM version because they found it faster and easier to search on CD-ROM.

Problems encountered when using the Internet as an information medium include the following (Gill \& Grout 1997:20):

- difficulty in finding suitable information of high quality

- information and Web sites are too frequently moved to new addresses

- a flood of poor quality material which makes it difficult to recognise valuable sources. 
In order to meet the need artists experience for images, several digital indexes to images have been produced. Examples of these indexes are (Layne 1994:33; Stam 1995:23):

- Art in Time

- World Painting Index

- Illustration Index

- Sculpture Index

- Index to Reproductions of American Painting

- Design \& Applied Arts Index.

Although it is possible to find databases and indexes that help artists find the images they need, several researchers have expressed their doubts regarding the success achieved in describing the images effectively (Brilliant 1988:122; Layne 1994:28-31). In most of the indexes, the images have to be described in words, and this is not always easy to do. Many works of art are untitled or are very difficult to put into words. The works of the abstract expressionists, for example, seem to most indexers to defy description in the terms usually employed in bibliographic indexes.

Artists also need information-retrieval tools to help them locate textual material. Although several databases meet this need, and information specialists are developing specialised art databases on an ongoing basis, the visual arts are not as well served in this area as are most of the other disciplines (Murator 1989:40; Greenhalgh 1996:97). Walter (1991:3) also found that, with online databases in the arts, there is usually limited subject coverage, poor retrospective indexing, inadequate currency, a lack of coordination among the services and difficulties with the vocabulary used. Added to these are problems relating to a shortage of staff in libraries to help with online searches and the charges involved in searching these databases (Reynolds 1995:72-73).

The following bibliographic databases listed by Brilliant (1988:126) and Martinez (1998:33-34) have proved valuable to visual artists:

- Columbia Libraries Information Online (CLIO)

- Art Index

- Répertoire International de la Littérature de l'Art (RILA)

- Avery Index to Architectural Periodicals

- Zeitschrift für Kunstgeschichte

- Répertoire d'Art et d'Archéologie

- Annuario Bibliografico di Storia dell'Arte

- Fasti Archaeologici

- Bibliography of the History of Art (BHA)

- Arts \& Humanities Citation Index (A\&HCI)

- ARTbibliographies Modern (ABM)

- Archaeologisches Bibliographie

Although RILA ceased to exist in 1989 and was continued by BHA, artists have continued to use RILA on CD$\mathrm{ROM}$, and find it very valuable.

Reynolds (1995:65) identified a need for full-text databases for artists. She found that there were tremendous difficulties in providing adequate subject access in the arts, which means that artists would benefit from free text searching as opposed to merely being able to search through titles, subject headings and perhaps abstracts.

Several researchers including Fleming (1993:1) and Reynolds (1995:67) found that artists are not favourably disposed towards computerised databases, but as they become more user-friendly, artists are showing greater interest in these bibliographic sources (Crawford 1986:573). Van Zijl and Gericke (1998:27) also found that the majority of artists find these databases useful, if not essential.

Authors have found that there are great problems relating to providing sufficient access points for images and art literature because, for example, the names of artists and works of art might be different in different languages and much of the material is of a philosophical nature. Others, however, believe that very accurate access is in fact provided. Wiberley (1983:421-430) found that humanists search mainly for names of people or of particular works or for geographical places or collective nouns. They also have been found to search for chronological periods, art movements and names of disciplines (Bates, Wilde \& Siegfried 1993:1). This author believes that with carefullymaintained authority files in the databases, searching on databases for the arts could be relatively accurate.

There is a certain amount of discrepancy amongst authors regarding the relative importance of databases to visual artists. Stam (1994:278) found that Art Index is the foremost periodical index used by artists and that World Painting Index is the most used database for locating reproductions. In her study, the latter database is closely followed in 
popularity by Illustration Index and Index to Reproductions of American Painting. Stam (1994:278) also found that Design \& Applied Arts Index, ABM, RILA and Art \& Humanities Citation Index are used occasionally.

Brilliant (1988:126-127), on the other hand, believes that CLIO is the most useful database for artists who need to locate relevant publications. This is followed in popularity by Art Index and RILA as well as Avery Index to Architectural Periodicals for those interested in architecture. $A B M$ is on the next level down as far as popularity is concerned.

Sykes-Austin (1991:14) found that Art Index on CD-ROM, RILA and ABM are valuable to artists, and Martinez (1998:33) found that the Bibliography of the History of Art (BHA) was the most comprehensive and up-to-date bibliography of art history.

Saule (1992:600) and Fleming (1993:1) both found that artists were not very keen on using new technology, including bibliographic databases, especially those which are available digitally. Saule (1992:602) found that humanities scholars are also unfamiliar with the range of databases available to them and do not make much use of them.

\section{Research methodology}

The author carried out a cross-sectional survey as the empirical part of her Master's studies (Van Zij1 2000) at the University of South Africa to establish the information needs and information-seeking behaviour of South African visual artists. The instrument used was a self-administered questionnaire.

The population consisted of the more information-literate visual artists in South Africa, and the sampling frame included lecturers in all branches of the visual arts at universities and technikons, art teachers in South African high schools and members of art societies. Questionnaires were distributed to art lecturers whose names had been forwarded to the author by the institutions concerned, registered members of an art society known as the South African National Association for the Visual Arts (SANAVA) and to a randomly selected sample of high school art teachers. A second questionnaire was sent out three weeks later to those who had not responded to the first questionnaire.

Out of the 286 questionnaires distributed, 123 were finally returned. The response rate was thus $43 \%$. Two institutions inexplicably had a nil response rate. One was a university offering degrees in the fine arts up to a doctoral level, and the other was a technikon which offers diplomas in fashion design but no other branches of the arts.

Although the author had hoped for a better response rate, the questionnaires returned cover most categories of visual artists, and there are enough respondents to allow for a comparative, in-depth study of the information needs and information-seeking behaviour of artists.

\section{Results}

\section{Usefulness of art databases to South African artists}

Although South African visual artists (particularly those who lecture at universities and technikons) do use some of the databases and indexes provided for artists to a certain extent, a large proportion of respondents have never used the majority of the frequently cited databases.

Respondents had to rate several art-related databases according to their usefulness to them. These include Art Index, Art Abstracts, ABM, RILA, A\&HCI, Design \& Applied Arts Index, World Painting Index, Art in Time, Illustration Index, Sculpture Index, Index to Reproductions of American Painting, CLIO, Avery Index to Architectural Periodicals and World Art Catalogue Bulletin. They could also add other databases they found to be useful. In this last category, the following databases were mentioned by one respondent each: South African Artists Bulletin, MLA (the author is not familiar with this database), British Journal of Photography Index, Amazon.com and EbscoHost.

Figure 1 shows the extent to which South African artists use the more widely used databases and indexes. This figure paints a dismal picture of the extent to which even the more information-literate artists in South Africa use bibliographic and other databases and indexes. In each case, a large number of artists have never used the databases. Even in the use of Art Index and Art Abstracts, which are the most used databases amongst South African artists, there is a high incidence of non-use. In total, 51 (41,5\%) of the 123 respondents have never used Art Index, 


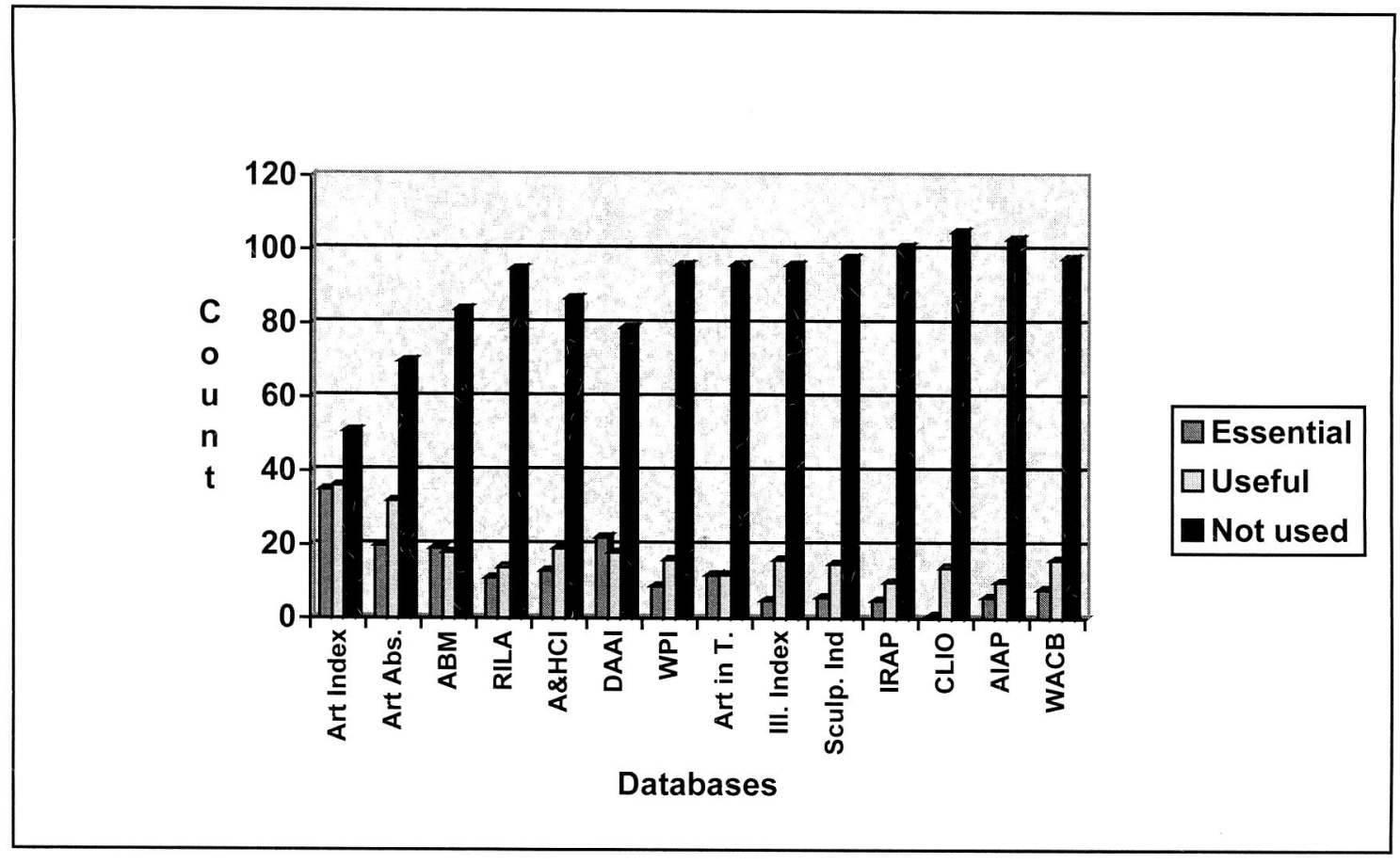

Figure 1 Usefulness of databases

and $70(56,9 \%)$ have never used Art Abstracts. This high proportion of non-use of bibliographic and other databases is clearly much higher than that found to be the case in studies in the U.S.A., Britain and Europe. Regrettably, no reason for this comes to the fore. It is possible that subscriptions to these databases in South Africa have become so prohibitively expensive that very few information services can afford to subscribe to them.

When it comes to the perceived usefulness of the various databases to artists, respondents indicated as follows regarding the indispensability of databases or indexes:

- Art Index

- Design \& Applied Arts Index

- Art Abstracts

- ARTbibliographies Modern

- Arts \& Humanities Citation Index

- Art in Time

- RILA

- World Painting Index

- World Art Catalogue Bulletin

- Sculpture Index

- Avery Index to Architectural Periodicals

- Illustration Index

- Index to Reproductions of American Painting

- CLIO

$$
\begin{gathered}
35(28,5 \%) \\
22(17,9 \%) \\
20(16,3 \%) \\
19(15,4 \%) \\
13(10,6 \%) \\
12(9,8 \%) \\
11(8,9 \%) \\
9(7,3 \%) \\
8(6,5 \%) \\
6(4,9 \%) \\
6(4,9 \%) \\
5(4,1 \%) \\
5(4,1 \%) \\
1(0,8 \%)
\end{gathered}
$$

It is clear from these statistics that even the more popular databases do not appear to be indispensable to a large proportion of South African artists.

When the "indispensable" and "useful" responses are taken as a single positive response for the databases, the picture is not much different. Given again in order of importance, the following pattern emerges:

- Art Index

- Art Abstracts

- Design \& Applied Arts Index

- $A B M$

- Arts \& Humanities Citation Index

- RILA

- World Painting Index

- Art in Time

- World Art Catalogue Bulletin
$71(57,7 \%)$

$52(42,3 \%)$

$40(32,5 \%)$

$37(30,1 \%)$

$32(26,0 \%)$

$25(20,3 \%)$

$25(20,3 \%)$

$24(19,5 \%)$

$24(19,5 \%)$ 
- Illustration Index

$21(17,1 \%)$

- Sculpture Index

$21(17,1 \%)$

- Avery Index to Architectural Periodicals

$16(13,0 \%)$

- CLIO

$15(12,2 \%)$

- Index to Reproductions of American Painting

$15(12,1 \%)$

The only databases which have any notable value for South African visual artists are Art Index, Art Abstracts, Design \& Applied Arts Index and ABM. Art \& Humanities Citation Index is next in popularity overall. The other databases all have a few adherents who believe that they are valuable or indispensable, but the interest in these is limited.

It seems that the rest of the databases that were found so useful to artists in other countries have little value to South African artists. Databases like CLIO, BHA and RILA do not have much of a following among these information users.

It was found that certain independent variables had an effect on the use artists make of databases and indexes.

\section{Gender and usefulness of databases}

Gender is, to a certain degree, related to the extent to which artists use databases. In the sample used, $66(53,7 \%)$ of the respondents were female, and $57(46,3 \%)$ were male. Females show a slightly higher incidence of finding some databases indispensable. With Art Index, for example, 21,1\% of male artists indicated that the database was essential, as compared to $36,8 \%$ of female respondents. With Art Abstracts as well, female artists showed a greater interest. A total of $21,1 \%$ of the female artists consider this database indispensable, whilst only $12,1 \%$ of the males concur. When it comes to $A B M, 12,1 \%$ of males indicated that this was indispensable, as opposed to $19,3 \%$ of the female artists. When it came to $A \& H C I, 7,6 \%$ of males voted it to be indispensable, whilst $14 \%$ of females shared this view. For the other databases or indexes, the difference was not so marked, and in some cases males showed a higher incidence of use than their female counterparts, but overall, female artists were more inclined to use databases and indexes.

\section{Age and usefulness of databases}

In the sample used, $11(8,9 \%)$ of the respondents were below 30 years old, $32(26 \%)$ were aged between 30 and 39 years, $45(36,6 \%)$ were aged 40 to 49 years and $35(28,5 \%)$ were 50 years and older. When age was taken as the influencing variable, it was found that as a rule, artists above the age of 40 years are more likely to use databases and indexes than are the younger artists. In Table 1, the percentage of users in each age group who consider the listed databases to be indispensable is given.

Table 1 Extent to which different age groups find databases essential

\begin{tabular}{lcccc}
\hline \multicolumn{1}{c}{ Database / Index } & Below $30 \%$ & $30-39 \%$ & $40-49 \%$ & Above $50 \%$ \\
\hline Art Index & 18.2 & 21.9 & 35.6 & 28.6 \\
Art Abstracts & 0 & 12.5 & 24.4 & 14.3 \\
ABM & 9.1 & 9.4 & 20 & 17.1 \\
RILA & 0 & 3.1 & 13.3 & 11.4 \\
A\&HCI & 9.1 & 6.3 & 11.1 & 14.3 \\
Design \& A. Arts Index & 9.1 & 18.8 & 13.3 & 25.7 \\
World Painting Index & 9.1 & 6.3 & 2.2 & 14.3 \\
Illustration Index & 0 & 0 & 4.4 & 8.6 \\
Sculpture Index & 18.2 & 0 & 6.7 & 2.9 \\
IRAP & 9.1 & 3.1 & 2.2 & 5.7 \\
CLIO & 0 & 0 & 2.2 & 0 \\
Avery Index & 9.1 & 0 & 6.7 & 5.7 \\
\hline
\end{tabular}

In most instances, the older artists display a greater incidence of using the listed databases. The only exceptions here are Sculpture Index, Index to Reproductions of American Painting and Avery Index. This pattern changes somewhat 
when the "indispensable" and "useful" responses are combined into a single "useful" category. Only the most interesting results will be reflected in Table 2; for the rest of the databases, the patterns in Table 1 are repeated.

Table 2 Extent to which databases are "useful" or "essential"and age group

\begin{tabular}{lcccc}
\hline \multicolumn{1}{c}{ Database / Index } & Below $30 \%$ & $30-39 \%$ & $40-49 \%$ & Above $50 \%$ \\
\hline Art Index & 63.6 & 59.3 & 57.8 & 54.3 \\
Art Abstracts & 27.3 & 40.6 & 51.1 & 37.1 \\
A\&HCI & 36.4 & 25 & 26.7 & 22.9 \\
Design \& A. Arts Index & 45.5 & 34.4 & 24.4 & 37.1 \\
World Painting Index & 27.3 & 15.6 & 17.8 & 25.7 \\
Art in Time & 27.3 & 15.6 & 17.8 & 22.9 \\
\hline
\end{tabular}

Art Index, A\&HCI, Art in Time and Design \& Applied Arts Index proved to be very useful to all age groups. In fact, when these two categories were combined, the under 30 years group demonstrated that they make extensive use of these databases. Art Abstracts is also valuable to all age groups. When "useful" and "essential" responses are combined, it is the 30-39 years group that shows the greatest interest in these databases.

\section{Working milieu and usefulness of databases}

The working milieu of the respondents has a strong influence on the amount of use the artists make of various databases, as can be seen in Table 3. In this table, the categories into which artists are divided are university lecturer, technikon lecturer, school art teacher and members of SANAVA. There were 31 university lecturers in the sample $(25,2 \%), 66$ technikon lecturers $(53,7 \%), 21$ high school teachers $(17,1 \%)$ and regrettably only 5 members of SANAVA (4,1\%). Although the number of respondents in the latter group is too small to effectively apply any statistical tests, it was decided to record statistics relating to this group because they are the only respondents who do not represent the educational sector of artists in South Africa. It will be noted that, in certain cases, the total of (usefulness + never used) is not $100 \%$. This is because in some cases, respondents had used the database in question but had found it to be "useless".

Table 3 Usefulness of databases according to the affiliation of artists

\begin{tabular}{|c|c|c|c|c|c|c|c|c|}
\hline Database/Index & $\begin{array}{l}\text { Univ. } \\
\text { Useful }\end{array}$ & $\begin{array}{c}\text { Univ. } \\
\text { Never } \\
\text { used } \\
\%\end{array}$ & $\begin{array}{l}\text { Tech. } \\
\text { Useful }\end{array}$ & $\begin{array}{l}\text { Tech. } \\
\text { Never } \\
\text { used } \\
\%\end{array}$ & $\begin{array}{l}\text { School } \\
\text { Useful }\end{array}$ & $\begin{array}{c}\text { School } \\
\text { Never } \\
\text { used } \\
\%\end{array}$ & $\begin{array}{l}\text { SAN. } \\
\text { Useful }\end{array}$ & $\begin{array}{c}\text { SAN. } \\
\text { Never } \\
\text { used } \\
\%\end{array}$ \\
\hline Art Index & 64.5 & 32.3 & 59.9 & 40.9 & 47.6 & 52.4 & 40 & 60 \\
\hline Art Abstracts & 58.1 & 38.7 & 34.8 & 65.2 & 42.9 & 57.1 & 40 & 60 \\
\hline $\mathrm{ABM}$ & 51.6 & 45.2 & 19.7 & 78.8 & 33.3 & 66.7 & 20 & 80 \\
\hline RILA & 35.5 & 58.1 & 13.6 & 84.8 & 19.0 & 81.0 & 20 & 80 \\
\hline $\mathrm{A} \& \mathrm{HCI}$ & 32.3 & 54.8 & 27.3 & 72.7 & 19.0 & 81.0 & 0 & 100 \\
\hline Des. \& A. Arts & 22.6 & 64.5 & 40.9 & 59.1 & 23.8 & 76.2 & 20 & 80 \\
\hline World P. Index & 25.8 & 71.0 & 15.2 & 83.3 & 28.6 & 71.4 & 20 & 80 \\
\hline Art in Time & 22.6 & 67.7 & 15.2 & 84.8 & 28.6 & 71.4 & 20 & 80 \\
\hline Illustration Index & 19.4 & 67.7 & 16.7 & 80.3 & 14.3 & 85.7 & 20 & 80 \\
\hline Sculpture Index & 25.8 & 67.7 & 10.6 & 86.4 & 23.8 & 76.2 & 20 & 80 \\
\hline I.R. Am. Painting & 19.4 & 67.7 & 9.1 & 86.4 & 9.5 & 90.5 & 20 & 80 \\
\hline CLIO & 22.6 & 71.0 & 9.1 & 89.4 & 9.5 & 90.5 & 0 & 100 \\
\hline Avery Index & 19.4 & 71.0 & 9.1 & 89.4 & 19.0 & 81.0 & 0 & 100 \\
\hline W. Art Cat. Bull. & 22.6 & 74.2 & 15.2 & 84.8 & 28.6 & 71.4 & 20 & 80 \\
\hline
\end{tabular}


Table 3 shows that university lecturers are the greatest users of databases and that they use the greatest variety of databases. In the evaluation of all databases except the Design \& Applied Arts Index, World Painting Index, Art in Time and World Art Catalogue Bulletin, the university lecturers have the highest incidence of respondents who find the databases useful or indispensable. In all cases except the World Art Catalogue Bulletin, they have the lowest incidence of never having used the databases. It could be that the university lecturers have the greatest access to art databases.

The only database that produced completely different results was the Design \& Applied Arts Index. Because of the emphasis on the design aspect of art and on the applied arts in technikons, this discrepancy is to be expected. Twenty-seven $(40.9 \%)$ of the technikon lecturers indicated that this database is indispensable or useful, as opposed to seven $(22.6 \%)$ of the university lecturers. Even five $(23.8 \%)$ of the secondary school teachers shared this view - a higher proportion again than that of the university lecturers.

World Painting Index is more useful to teachers than to any of the other groups. Six (28.6\%) of the high school teachers find this database useful, as compared to eight $(25.8 \%)$ of the university lecturers, ten $(15.2 \%)$ of technikon lecturers and one (20\%) of the members of SANAVA. Art in Time and World Art Catalogue Bulletin are also more popular amongst the teachers than the other groups. These databases are more image-related than the other databases, which might explain their appeal to teachers who have to locate images to teach effectively.

University lecturers are the more critical users of databases. In several cases, these lecturers indicated that the databases in question were "useless". The only other group who indicated that some of the databases were "useless" was that comprising the technikon lecturers, but their negative responses were fewer. Databases which three or more university lecturers consider to be useless are A\&HCI, Design \& Applied Arts Index, Art in Time, Illustration Index, Index to Reproductions of American Painting and Avery Index to Architectural Periodicals.

The overall numbers of respondents who voted the databases to be "useless" are as follows:

Index to Reproductions of American Painting (5.7\%), Illustration Index (4.9\%), A\&HCI (3.3\%), Avery

Index to Architectural Periodicals (3.3\%), Design \& Applied Arts Index (3.3\%), Sculpture Index (3.3\%),

Art in Time (2.4\%), CLIO (2.4\%), RILA (2.4\%), ABM (1.6\%), Art Abstracts (0.8\%), Art Index (0.8\%),

World Art Catalogue Bulletin (0.8\%).

The author found that the most useful databases for South African artists are Art Index, Art Abstracts and ABM, followed by RILA and $A \& H C I$. Another useful database for technikon lecturers is Design \& Applied Arts Index. Of some use to secondary school teachers are the databases World Painting Index, Art in Time and World Art Catalogue Bulletin.

Members of SANAVA show little interest in any of the databases. It is probable that the type of information required by studio and other artists is not covered by these databases. It is also likely that these artists do not have the access to these databases which is afforded to the other groups of artists.

\section{Qualifications and usefulness of databases}

Another independent variable that has an effect on the usefulness of databases is the educational level of the respondents. The majority of respondents (65) have postgraduate qualifications. Twenty-seven have art-related Bachelor's degrees, 29 have technikon qualifications up to B.Tech. level and 18 have teaching qualifications. Overall, it was found that those with postgraduate qualifications are the most likely to use databases in their quest for information. This can be seen in Table 4. In this table the categories of "useful" and "indispensable" have been combined into a single category because this gives a clearer picture of the trends. Only statistics relating to artists with an art-related B.A. degree, a technikon diploma or postgraduate qualifications are given in this table as those relating to artists with other qualification are not very noteworthy.

Table 4 shows that in most cases, the greatest users of the databases are respondents with postgraduate qualifications. This is usually followed by those with Bachelor's degrees and then come those with technikon qualifications.

The exceptions to this rule are Design \& Applied Arts Index in which case the majority of users have technikon qualifications, and World Painting Index, Art in Time and Illustration Index in which cases artists with B.A. qualifications showed the most interest.

It must be remembered that subscriptions to the databases in question are very expensive to South African subscribers and only the financially robust institutions can afford them. It must also be remembered that in some libraries, only users studying for postgraduate qualifications are permitted to use these databases. The most 
important reason why artists with postgraduate qualifications make greater use of databases and indexes is probably that these artists have had to conduct research to acquire their qualifications. This would have forced them to search for information beyond their libraries' collections and this kind of information is best found in electronic or print databases or indexes.

Table 4 Effect of qualifications on use of databases

\begin{tabular}{lccc}
\hline \multicolumn{1}{c}{ Database / Index } & B.A. \% & Tech. Qual. \% & Postgraduate \% \\
\hline Art Index & 59.3 & 48.3 & 64.6 \\
Art Abstracts & 37.0 & 13.8 & 53.8 \\
ABM & 25.9 & 10.3 & 43.1 \\
RILA & 18.5 & 10.3 & 27.7 \\
A\&HCI & 22.2 & 10.3 & 35.4 \\
Design \& Applied Arts Index & 29.6 & 34.5 & 32.3 \\
World Painting Index & 22.2 & 10.3 & 18.5 \\
Art in Time & 18.5 & 13.8 & 15.4 \\
Illustration Index & 18.5 & 10.3 & 13.8 \\
Sculpture Index & 18.5 & 10.3 & 20 \\
Ind. to Rep. Of American Painting & 7.4 & 6.9 & 10.8 \\
CLIO & 3.7 & 0 & 20 \\
Avery Index & 11.1 & 3.4 & 20 \\
World Art Catalogue Bulletin & 18.5 & 17.2 & 23.1 \\
\hline
\end{tabular}

\section{Field of interest and usefulness of databases}

Predictably, the fields of interest and/or lecturing fields of artists have an influence on the perceived usefulness of the various databases. The author found that just because an artist lectures in one field of art, this is not necessarily his primary or only interest. For this reason, the lecturing field is handled as one variable and the artists' fields of interest as another. Although some of the categories proved to be small, the author believes that certain trends can be detected in the data, although statistical significance cannot be tested with such small groups.

Table 5 Usefulness of databases to artists lecturing in certain fields

\begin{tabular}{|c|c|c|c|c|c|c|c|}
\hline Database / Index & Unknown & History of art & $\begin{array}{c}\text { Graphic } \\
\text { design } \\
\%\end{array}$ & $\begin{array}{c}\text { Photo- } \\
\text { graphy } \\
\%\end{array}$ & $\begin{array}{c}\text { Textile } \\
\text { design } \\
\%\end{array}$ & $\begin{array}{c}\text { Jewel. } \\
\text { design } \\
\%\end{array}$ & $\begin{array}{c}\text { Fine } \\
\text { arts } \\
\%\end{array}$ \\
\hline Art Index & 85.7 & 86.6 & 60 & 25 & 28.6 & 33.3 & 60.4 \\
\hline Art Abstracts & 45.9 & 80 & 40 & 16.6 & 0 & 0 & 45.8 \\
\hline $\mathrm{ABM}$ & 28.6 & 66.7 & 26.7 & 8.3 & 0 & 0 & 31.3 \\
\hline RILA & 28.6 & 40 & 20 & 8.3 & 0 & 0 & 18.8 \\
\hline $\mathrm{A} \& \mathrm{HCI}$ & 57.1 & 33.3 & 33.3 & 8.3 & 0 & 33.3 & 22.9 \\
\hline Des. \& A.A. Ind. & 45.9 & 40 & 66.7 & 16.6 & 57.1 & 0 & 14.6 \\
\hline World. Paint. Ind. & 14.3 & 20 & 26.7 & 8.3 & 14.3 & 0 & 20.8 \\
\hline Art in Time & 14.3 & 20 & 20 & 8.3 & 28.6 & 0 & 16.7 \\
\hline Illustration Index & 14.3 & 20 & 26.7 & 16.6 & 14.3 & 0 & 12.5 \\
\hline Sculpture Index & 14.3 & 20 & 6.7 & 0 & 0 & 0 & 22.9 \\
\hline IRAP & 14.3 & 20 & 13.3 & 8.3 & 0 & 0 & 12.5 \\
\hline CLIO & 14.3 & 20 & 13.3 & 8.3 & 0 & 0 & 12.5 \\
\hline Avery & 14.3 & 13.3 & 6.7 & 8.3 & 0 & 0 & 12.5 \\
\hline W. Art Cat. Bull. & 14.3 & 26.7 & 20 & 0 & 14.3 & 0 & 18.8 \\
\hline
\end{tabular}


Jewelry design lecturers showed little or no interest in the information available in databases, as can be seen in Table 5. It was found, however, that out of the 10 respondents who are interested in jewelry design but do not necessarily lecture in that field, seven (70\%) find Art Index useful. A small amount of interest was shown in Art Abstracts (three, or 30\%) and in $A B M, A \& H C I$ and Design and Applied Arts Index (two, or $20 \%$ in each case).

Textile designers showed only slightly more interest in these databases. Out of seven textile design lecturers, four (57.1\%) of the respondents indicated that Design \& Applied Arts Index is useful to them. Concerning both Art Index and Art in Time, two (28.6\%) gave a positive response, as did one (14.3\%) regarding the usefulness of World Painting Index, Illustration Index and World Art Catalogue Bulletin. Apart from these, no databases were used.

Other groups of lecturers who demonstrated little interest in the databases are the sculptors and ceramicists. The interest demonstrated by these groups was so small that their statistics have been incorporated in Table 5 in the "fine arts" category for analysis. It is interesting to note that out of the four sculpture lecturers, only one indicated that Sculpture Index is useful.

Photographers also have little use for databases. As far as photography lecturers are concerned, the only database in which more than a 20\% interest was shown was Art Index, which three out of the twelve respondents (25\%) find useful. Among those whose field of interest is photography, however, nine out of 32 respondents (28.1\%) find World Painting Index useful and seven (21.9\%) respondents find CLIO useful.

Fine arts lecturers are also not very strongly drawn towards the databases available for artists, although $60.4 \%$ (29 out of 40) consider Art Index to be useful. Art Abstracts (22 respondents or 45.8\%) is also fairly well used by this group of artists and 22.9\% (11 respondents) find Sculpture Index useful. In the latter case, this group showed more interest than all the other groups. Two other databases or indexes in which fine arts lecturers show more interest than some of the other groups are the Avery Index to Architectural Periodicals (six respondents or 12.5\%) and World Art Catalogue Bulletin (nine respondents or 18.8\%).

Although respondents who lecture in ceramics showed very little interest in the databases and indexes in question, those who are interested in ceramics showed a particularly high interest in many of the databases. As these respondents also demonstrated an interest in other artistic fields, it could merely be coincidental that ceramics enthusiasts are also those who are interested in databases because of their interest in other fields of artistic pursuits. This group, however, showed relatively the highest interest in Illustration Index (10 out of 27, or 37\%), Avery Index to Architectural Periodicals (eight, or 29.6\%), World Painting Index (nine, or 33.3\%), RILA (eight, or 29.6\%) and Art in Time (nine, or 33.3\%).

Graphic design lecturers overall do not demonstrate a great interest in using the databases, but some of the databases proved to be useful to this group. They are the greatest users of Design \& Applied Arts Index - 10 out of the 15 artists in this group (66.7\%) find this index useful. As four of the artists in this group find World Painting Index useful, this is also one of the databases in which graphic designers show more interest than do the other groups. Illustration Index (four respondents marked this as useful) and Art in Time (three respondents) are also more popular among this group than other groups of artists. Art Index is useful to nine respondents in this group.

Amongst those artists whose special field of interest is unknown (including the members of SANAVA), there is a considerable interest in databases and indexes. This group shows the most interest in $A \& H C I$. Four out of the seven respondents in this group (57,1\%) indicated that this was useful to them. Art Index (six or 85.7\%) and Art Abstracts (three or $42.9 \%$ ) are also valued by these artists.

By far the most frequent users of databases and indexes are the art historians and theorists. This is to be expected, as this branch of art is mainly theoretical. This means that much of the information they require comes from published works. Table 5 shows that this group makes the most extensive use of databases. The extent to which they find Art Abstracts useful is of particular interest because here 12 out of the 15 respondents $(80 \%)$ indicate that this database is useful. This interest is much higher than that of the other groups. Art historians also show a tremendous interest in Art Index (86.6\%).

By and large, the amount of interest in these databases and indexes is much less than one would be led to believe. All of the other research projects in this regard, however, have been carried out in the U.S.A. and Europe, where access to these databases is possibly easier than in South Africa. A very large proportion of respondents have never used most of the databases, and even highly lauded databases like CLIO and RILA attract a very small following in South Africa.

Even amongst users of university libraries, which appear to offer a wider range of indexes and databases to their clients, the amount of enthusiasm for these is fairly limited. It can clearly be stated that South African visual artists 
do not rely heavily on these databases to find their information. This could be due to a lack of access to these databases, or, alternately, a failure on the part of information services to market the availability of these to library and information service clients. Either way, very important sources of information are being sidestepped by artists in South Africa.

Another worrying fact that comes to light is that artists outside the tertiary educational environment make little use of databases and indexes. It is possible that these artists' information needs do not include the type of bibliographic, graphic or textual information one finds in these information sources. It is also possible that these artists have no way of accessing the databases in question at the information services they use most.

\section{Success in the searching of databases}

In an attempt to ascertain whether training in the use of OPAC's and the databases in question improves the amount of success researchers have in using the databases, it was decided to correlate success in the use of databases with training received by respondents. Saule (1992: 604) found in her study that humanists need to be taught about the databases available to them and must be shown how to use these.Table 6 shows that training in the use of OPAC's has a positive effect on the success artists have in using databases. There is a higher proportion of artists who are both "very successful" and "fairly successful" amongst those who have received training in the use of OPAC's than amongst those who have not, or do not know if such training has been received. The proportion of respondents who believe that they are "fairly successful" is slightly more than twice that of respondents who have received no such training. This confirms a finding by Fleming (1993:4) that there is a connection between library instruction and an improvement in research skills.

Table 6 Correlation between OPAC training \& success in finding information in databases

\begin{tabular}{|c|c|c|c|c|c|c|c|c|}
\hline & & & \multicolumn{6}{|c|}{ Success in using databases } \\
\hline & & & $\begin{array}{c}\text { Very } \\
\text { successful }\end{array}$ & $\begin{array}{c}\text { Fairly } \\
\text { successful }\end{array}$ & Unsuccessful & $\begin{array}{c}\text { Not } \\
\text { applicable }\end{array}$ & No data & Total \\
\hline \multirow{7}{*}{$\begin{array}{l}\text { Training in use of } \\
\text { library catalogue }\end{array}$} & Yes & Count & 9 & 44 & 3 & 27 & 2 & 85 \\
\hline & & $\begin{array}{l}\% \text { within Training } \\
\text { in use of library } \\
\text { catalogue }\end{array}$ & $10.6 \%$ & $51.8 \%$ & $3.5 \%$ & $31.8 \%$ & $2.4 \%$ & $100 \%$ \\
\hline & No & $\begin{array}{l}\text { Count } \\
\% \text { within Training } \\
\text { in use of library }\end{array}$ & 1 & 4 & & 10 & 1 & 16 \\
\hline & & catalogue & $6.3 \%$ & $25 \%$ & & $62.5 \%$ & $6.3 \%$ & $100 \%$ \\
\hline & & Count & 0 & 7 & & 14 & 1 & 22 \\
\hline & Don’t & $\begin{array}{l}\% \text { within Training } \\
\text { in use of library }\end{array}$ & & & & & & \\
\hline & know & catalogue & & $31.8 \%$ & & $63.6 \%$ & $4.5 \%$ & $100 \%$ \\
\hline \multirow[t]{3}{*}{ Total } & & Count & 10 & 55 & 3 & 51 & 4 & 123 \\
\hline & & $\begin{array}{l}\% \text { within Training } \\
\text { in use of library }\end{array}$ & & & & & & \\
\hline & & catalogue & $8.1 \%$ & $44.7 \%$ & $2.4 \%$ & $41.5 \%$ & $3.3 \%$ & $100 \%$ \\
\hline
\end{tabular}

Table 7 shows furthermore that special training in searching databases also has a positive influence on the success experienced by visual artists when they are searching for material on databases. A total of $13 \%$ of respondents who had received such training find that they are "very successful" in finding the information they require in databases. 
Table 7 Correlation between database training and success in use of databases

\begin{tabular}{|c|c|c|c|c|c|c|c|c|}
\hline & & & \multicolumn{6}{|c|}{ Success in using databases } \\
\hline & & & $\begin{array}{c}\text { Very } \\
\text { successful }\end{array}$ & $\begin{array}{c}\text { Fairly } \\
\text { successful }\end{array}$ & Unsuccessful & $\begin{array}{c}\text { Not } \\
\text { applicable }\end{array}$ & No data & Total \\
\hline \multirow{10}{*}{$\begin{array}{l}\text { Training in use } \\
\text { of library } \\
\text { catalogue }\end{array}$} & Yes & Count & 9 & 35 & 3 & 20 & 2 & 69 \\
\hline & & $\begin{array}{l}\% \text { within Training } \\
\text { in use of library }\end{array}$ & & & & & & \\
\hline & & catalogue & $13.0 \%$ & $50.7 \%$ & $4.3 \%$ & $29.0 \%$ & $2.9 \%$ & $100 \%$ \\
\hline & No & Count & 1 & 7 & & 11 & 1 & 20 \\
\hline & & $\begin{array}{l}\% \text { within Training } \\
\text { in use of library }\end{array}$ & & & & & & \\
\hline & & catalogue & $5.0 \%$ & $35.0 \%$ & & $55.0 \%$ & $5.0 \%$ & $100 \%$ \\
\hline & & Count & & 13 & & 20 & 1 & 34 \\
\hline & & $\%$ within Training & & & & & & \\
\hline & Don't & in use of library & & & & & & \\
\hline & know & catalogue & & $38.2 \%$ & & $58.8 \%$ & $2.9 \%$ & $100 \%$ \\
\hline \multirow[t]{4}{*}{ Total } & & Count & 10 & 55 & 3 & 51 & 4 & 123 \\
\hline & & $\%$ within Training & & & & & & \\
\hline & & in use of library & & & & & & \\
\hline & & catalogue & $8.1 \%$ & $44.7 \%$ & $2.4 \%$ & $41.5 \%$ & $3.3 \%$ & $100 \%$ \\
\hline
\end{tabular}

A disturbing feature of both Tables 6 and 7 is the large proportion of artists who do not use the databases at all. These statistics are entered in the tables as "not applicable". It has to be added, however, that even those who have received no training in the use of databases find that they are fairly successful in using these. None of these respondents, except three in the group who have received training, answered that they were "unsuccessful" in using the databases. This leaves a large proportion who feel that their database use leads them to the information they want.

Table 8 Age and success in use of databases

\begin{tabular}{|c|c|c|c|c|c|c|c|c|}
\hline & & & \multicolumn{6}{|c|}{ Success in using databases } \\
\hline & & & Very & Fairly & & Not & & \\
\hline & & & successful & successful & Unsuccessful & applicable & No data & Total \\
\hline \multirow{8}{*}{$\begin{array}{l}\text { Age } \\
\text { group }\end{array}$} & Below 30 years & Count & & 6 & & 4 & 1 & 11 \\
\hline & & $\%$ within age group & & $54.5 \%$ & & $36.4 \%$ & $9.1 \%$ & $100 \%$ \\
\hline & $30-39$ years & Count & 3 & 12 & 1 & 15 & 1 & 32 \\
\hline & & $\%$ within age group & $9.4 \%$ & $37.5 \%$ & $3.1 \%$ & $46.9 \%$ & $3.1 \%$ & $100 \%$ \\
\hline & $40-49$ years & Count & 4 & 20 & & 20 & 1 & 45 \\
\hline & & $\%$ within age group & $8.9 \%$ & $44.4 \%$ & & $44.4 \%$ & $2.2 \%$ & $100 \%$ \\
\hline & 50 years and & Count & 3 & 17 & 2 & 12 & 1 & 35 \\
\hline & above & $\%$ within age group & $8.6 \%$ & $48.6 \%$ & $5.7 \%$ & $34.3 \%$ & $2.9 \%$ & $100 \%$ \\
\hline \multirow[t]{2}{*}{ Total } & & Count & 10 & 55 & 3 & 51 & 4 & 123 \\
\hline & & $\%$ within age group & $8.1 \%$ & $44.7 \%$ & $2.4 \%$ & $41.5 \%$ & $3.3 \%$ & $100 \%$ \\
\hline
\end{tabular}

Male and female artists are equally successful in using databases, but the age of respondents has a marked influence on the amount of success respondents have in searching on databases for certain information. This can be seen in Table 8 . The most confidant group is the under 30 age group where $54,5 \%$ of respondents feel that their searching is "fairly successful". No-one in this age group felt that their searching was unsuccessful. 
Although artists over the age of 50 are the second most confident group, in that $8,6 \%$ find their searching "very successful" and another $48,8 \%$ think they are "fairly successful", this is also the group with the largest proportion of "unsuccessful" responses.

The 30-39 age group was the least successful in using databases, as is seen in Table 8. This group is also the one that recorded the highest number of "not applicable" responses. This means that there are many of the databases that have never been used by the respondents in that group. Fifteen of the 34 respondents in this group have never used databases. The 40-49 years group, which came second last in their success in using databases, is also the one with the second largest number of "not applicable" responses. The more artists are exposed to databases, the more successful they become in using them.

When the working milieu of artists is taken as the influencing variable, it comes to light that university lecturers are the most successful in searching databases. In this group, 19 out of $31(61,3 \%)$ gave positive responses. This makes them the foremost group as far as success in searching databases is concerned. Technikon lecturers and high school art teachers share second place with 34 out of $66(51.5 \%)$ of the technikon lecturers indicating that they are either fairly, or very, successful at searching databases, as did 11 of the $21(52,4 \%)$ teachers. Least successful are members of SANAVA, in which group one out of five $(10 \%)$ believe that they are fairly successful.

As previously stated, the less respondents are exposed to databases, the less successful they seem to be. Those recording the most success in searching databases, have the lowest "not applicable" responses. The data reveal that university lecturers have the highest proportion of database users (only 35,5\% of these lecturers have never used databases), and the members of SANAVA the lowest (60\% have never used databases).

Table 9 reflects the level of success in searching databases enjoyed by respondents who lecture or practice in various branches of visual arts.

In the previous section, it was shown that art historians and art theorists are the greatest users of databases. They are also the most successful in searching these databases. In this study, two of the 16 history of art lecturers feel that they were very successful in finding the information they require whilst another 10 feel that they were fairly successful.

The graphic designers also display a measure of confidence in their database searching. Out of the 15 respondents in this group, two replied that they are very successful in their searches, and seven more believe that they are fairly successful in finding information on databases.

Most of the textile designers who use databases (four out of seven or $57,1 \%$ ) find that they are fairly successful in finding what they want in databases.

Fine arts lecturers (including painting, printmaking and drawing) are also fairly confident in their database searching skills. In this group, four of the 42 respondents $(9,5 \%)$ indicated that they are very successful and 17 $(40,5 \%)$ that they are fairly successful in their searches.

Although one of the 12 photography lecturers indicated that he/she was very successful in using databases and one was fairly successful, as a group photographers show little interest in databases. They are the group with the largest group of "not applicable" responses. Nine of the $12(75 \%)$ never use databases.

The lecturers in textile design and those whose field of expertise is unknown both indicated that four out of the seven find that they are fairly successful in searching databases and all of the lecturers in fashion design and interior design also gave this answer. Industrial design lecturers and ceramicists in this survey do not consider their database searching to be successful, however. In these latter two groups, none of the respondents were even "fairly" confident that they could search successfully.

Only three of the respondents felt that their searching of databases was unsuccessful. Out of those who have the courage or necessary access to look for information on databases and indexes, most feel that they are getting what they want. 
Table 9 Correlation between success in use of databases and lecturing fields

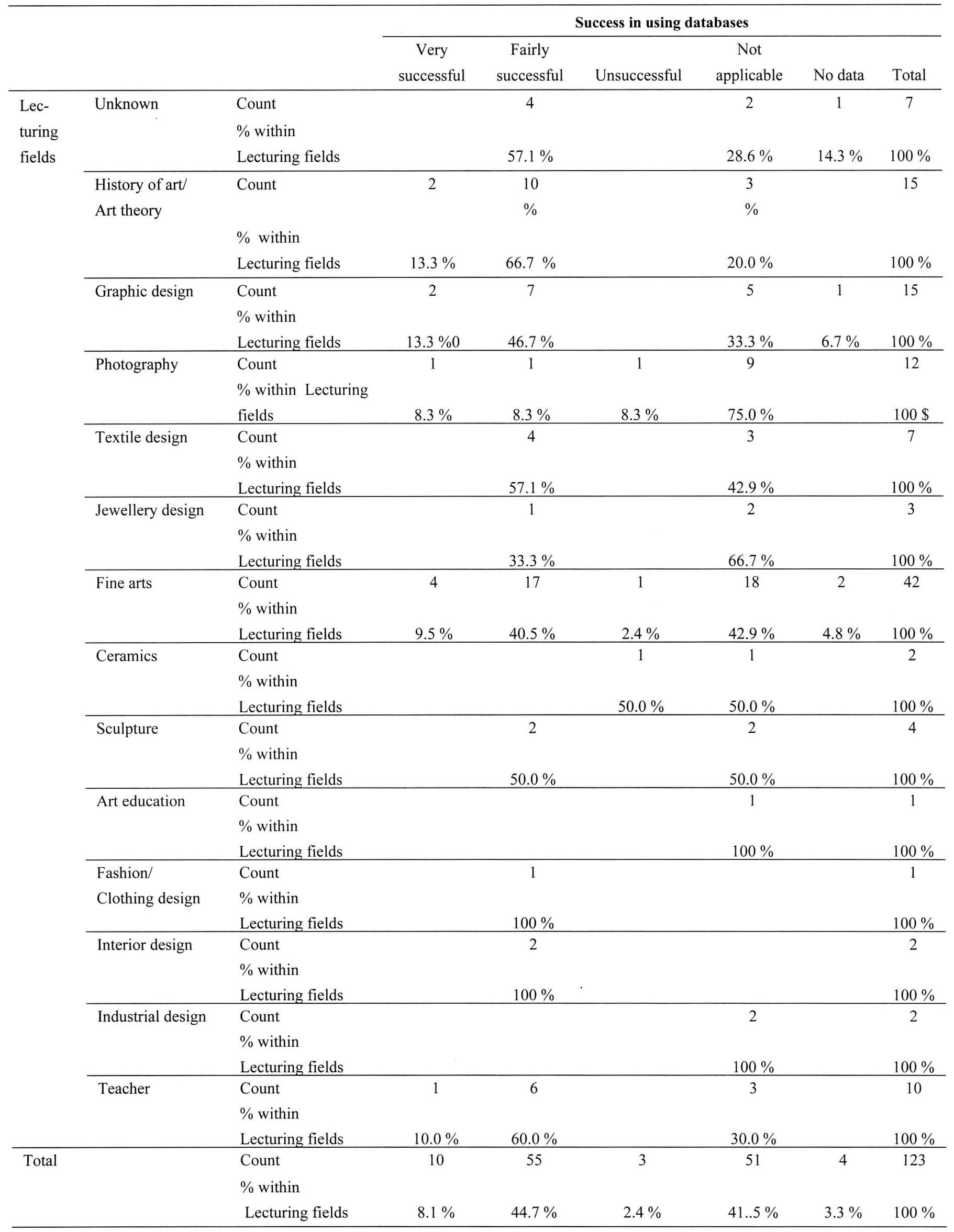




\section{Discussions and conclusions}

South African visual artists do not experience a great need to use databases such as CD-ROM databases and online bibliographic, graphic or textual databases as information retrieval resources. It also came to light that very few of the acclaimed art databases are available in South African libraries and information services. Many of the art librarians contacted at university and technikon libraries were not even aware of the existence of most of the databases.

Due to the high cost of subscribing to electronic databases, the author believes that the problem will not improve unless information agencies in South Africa enter into cooperative agreements with one another to ensure that the databases are available somewhere in this country for interested artists when they require them. It is also recommended that negotiations be entered into on a consortial, or even a national level to reduce subscription rates to these databases in South Africa, which is generally viewed at a developing country. As such, it is possible that the developed world will come to understand the information-impoverishing effect their high subscription rates have on the artists of South Africa.

Another problem is that artists are not informed about the potential value of electronic databases as information retrieval tools. It was also found that many artists are of the opinion that no databases are available at their libraries, whereas the author was informed by the librarians at those libraries that they were indeed subscribed to. Unless the usefulness and availability of databases is actively marketed amongst the visual artist community, these valuable information sources will remain unexploited and even unknown.

Art librarians clearly have an extensive task in making their databases known to their clients. It appears that most South African visual artists have not been exposed to the vast array of art databases during their past educational experiences and thus do not know how valuable they can be in their artistic and scholarly pursuits. The informationproviding sector should take responsibility for awakening an awareness of the art-related databases to enrich the information world of visual artists.

A recurring theme in the study was that it is extremely difficult to find information about local artists. Although there are various projects underway to develop databases about South African art and artists, none of these are readily available. No single body has taken the responsibility of ensuring a more coordinated gathering and disseminating of information about South African art. It is recommended that South African art museums or universities and technikons offering courses in the visual arts take the lead in developing databases of local art. If this is not done, many local artists who have achieved international and national fame could end their careers without any documented record of their art to help future artists and art historians. Possibly concerned art librarians should spearhead such ventures and make this invaluable contribution to the promotion of South African art.

Any art librarian will know that our artists are worth the effort.

\section{References}

Bates, M.J., Wilde, D.N. \& Siegfried, S. 1993. An analysis of search terminology used by humanities scholars: the Getty Online Searching Project report number 1. The library quarterly, 63(1):1-39.

Brilliant, R. 1988. How an art historian connects art objects and information. Library trends, 37(2):120-129.

Crawford, D. 1986. Meeting scholarly information needs in an automated environment: a humanists perspective. College \& research libraries, 47(11):569-574.

Fleming, M. 1993. Bibliographic instruction on electronic resources for the humanities. Libres: Library and information science research. Available: http://www.bubl.ac.uk/journals/lis/kn/libres/v03n0593.htm.

Gill, T. \& Grout, C. 1997. Finding and preserving visual arts resources on the Internet. Art libraries journal, 22(3):19-25.

Greenhalgh, M. 1996. Setting up and exploiting humanities research resources on the World Wide Web. Australian academic \& research libraries, 27(2):95-106.

Griffin, J.R. 1997. Fine art on multimedia CD-ROM and the Web. Computers in libraries, 17(4):63-67.

Jacso, P. \& Tiszai, J. 1996. Multimedia databases of fine arts CD-ROM and online. Database, 19(6):13-23.

Layne, S.S. 1994. Artists, art historians, and visual art information. The reference librarian, 47:23-35.

Martinez, K. 1998. The Research Libraries Group: new initiatives to improve access to art and architecture information. Art libraries journal, 23(1):30-37.

Muratori, F. 1989. How good an online searcher are you? Twenty questions about arts and humanities databases. Online, 13(1):40-42.

Reynolds, J. 1995. A brave new world: user studies in the humanities enter the electronic age. The reference librarian, 49/ 50:61-81. 
Saule, M.R. 1992. User instruction issues for databases in the humanities. Library trends, 40:596-613.

Stam, D.C. 1994. Libraries as a bridge between artist and society. Inspel, 29:275-282.

Stam, D.C. 1995. Artists and art libraries. Art libraries journal, 20(2):21-24.

Sykes-Austin, B. 1991. The Art Index on CD-ROM at the Avery Architectural and Fine Arts Library, Columbia University: a research study. Art documentation, 10(Spring):13-17.

Walter, N. 1991. Computerization in research in the visual arts. Art Documentation, 10(Spring):3-11.

Wiberley, S.E. 1983. Subject access in the humanities and the precision of the humanist's vocabulary. Library quarterly, 53(4):420-433.

Van Zijl, C. \& Gericke, E.M. 1998. Information-seeking patterns of artists and art scholars at the Vaal Triangle Technikon. South African journal of library and information science, 66(1):23-33.

Van Zijl, C.W. 2000. A model for service rendering to meet the information needs of South African artists. M.Inf. dissertation, Pretoria: University of South Africa. 